appointment was announced by memker universities, eighty were in Australia. Membership of the Association now comprises 102 universities, 15 university colleges and 4 other institutions, and some notes on the meetings of the Committee of Vice-Chancellors and Principals of the Universities of the United Kingdom are appended to the report.

\section{Fuel Abstracts and Current Titles}

THE annual report of the Council for the Institute of Fuel for the year 1959 makes reference to a new publication that will be called Fuel Abstracts and Current Titles (The Institute of Fuel. Report of the Council and Statement of Accounts for the year 1959. Pp. 16. London: Institute of Fuel, 1960). The first number is expected to be issued in mid-May. With the changes that took place in the reorganiza. tion of fuel research following the cessation of the activities at Greenwich of the Fuel Research Board, the Department of Scientific and Industrial Research had ceased to publish the most successful series of abstracts known as Fuel Abstracts. It was recognized by many fuel interests that the entire disappearance of the undertaking should not be allowed to occur, and therefore efforts have been made by the Institute to keep the venture alive. The problem has been to find the necessary financial support, and the Council of the Institute now announces that such further support has been promised for a period of development to a selfsupporting stage to an extent to justify the Institute in undertaking the responsibility of publication. One of the major problems of modern technological development is that of keeping in touch with the realiy important scientific advances. Accordingly, the function of such an undertaking is invaluable. This is particularly the case since one of the weaknesses of our modern scientific activity is the amount of repetitive work that is done, mainly because the records of past achievements have not been adequately reported, or that the investigators themselves have not been able to consult the volumes in which the work was originally reported. In other words, in the battle for progress our lines of communication have been weak. In the present context the moral is obvious, and it is hoped that the new venture will supply the necessary strength.

\section{Journals and the Science of Glass Making}

During the forty-three years of its existence, the Journal of the Society of Glass Technology achieved world-wide recognition as the leading publication in its field; this pre-eminence was due, in no small measure, to Emeritus Prof. W. E. S. Turner, who was editor for thirty-five years and a leading contributor to its pages. It is fitting that Prof. Turner should have been invited to write a foreword to the twin offspring of 'his' journal. Of recent years, glassmaking - and for that matter the related industry of ceramics-has become firmly based on fundamental science applied through a complex technology. New work for the glass industry has become increasingly varied and the Society of Glass Technology has decided to distinguish between that which is technological and that which is more a matter of pure chemistry and physics; papers of the former type will in future appear in Glass Technology, papers of the latter type in Physics and Chemistry of Glasses. In the first issue of Glass Technology there are articles on glass-furnace refractories and on glass-making machinery (1, No. 1; February 1960. Pp. $\mathrm{xl}+68$. Published bi-monthly. 25s. per issue or $135 s$, per volume). Physics and Chemistry of Glass contains papers on the strength of glass-fibres, the viscosity of sodium germanate glasses, the structure of boric oxide and borate glasses, and the change in the hard. ness of some simple glasses with increasing tem. perature (1, No. 1; February 1960. Pp. 54. Published bi-monthly. 25s. per issue or 135s. per volume). Each journal carries its own collection of appropriate abstracts. Both are edited by Prof. R. W. Douglas, who is to be congratulated on their excellent lay-out and presentation. A joint annual subscription can be obtained at $200 s$.

\section{Cytology}

A NEw Russian journal is to be devoted to cytology (Cytology, 1, No. 1. Editor in chief, A. S. Troshin. (In Russian.) Pp. 140. Moscow : Akademii Nauk SSSR, 1959). 'Cytology' is regarded for this purpose as encompassing a rather wide field, including nerve and muscle physiology and radiation biology, for example, as well as more narrowly cytological topies. It seems clear that there is at the present time in the Soviet Union a considerable expansion of effort and widening of interests, so far as studies at the cellular and sub-cellular levels are concerned. The recognition in the editorial preface of Cytology of the fact that contributions from the U.S.S.R. have lagged behind foreign work in some fields of cytology (especially in sub-microscopic structure, cycogenetics and cytochemistry) is unfortunately underlined to some extent by the contents of several of the papers in the first issue. The future development of cell biology in the U.S.S.R. will be watched with a great and friendly interest. It is therefore very much to be hoped that, until such time as a complete trans. lation service is available for this journal, there will be included, in addition to the present contents list in English, an English summary of each paper in future issues.

\section{Russian Journal of Physical Chemistry}

THE Chemical Society, in co-operation with the Department of Scientific and Industrial Research, is issuing a translation of the Russian Journal of Physical Chemistry, beginning with the Russian July 1959 issue. The English version appears about three months after the Russian, and each part contains about twenty illustrated papers and shorter notes. The English editor is R. P. Bell. Each number is of about 112 pages, $8 \frac{1}{2} \times 11$ in., in covers. Most of the papers are quite short and a wide field of interest is covered. Much very good work in physical chemistry has becn appearing in the U.S.S.R. (che tradition goes back over a long period of time) and chemists generally will be glad to have this trenslation available. The print is clear. The symbols in the mathematical equations are rather small, although they are clear. It is noticed that Russian translations of English and American works are referred to instead of the originals. The price of the first eighteen monthly issues (cor. responding with the Russian issues for July 1959December 1960 ) is $£ 45$ or 135 dollars, with a reduction of 25 per cent for colleges and universities. Thereafter, the annual subseription, beginning with the Russian January issue, will be $£ 30$ or 90 dollars, with the same reduction. The world distributors are CleaverHume Press, Ltd., 31 Wright's Lane, London, W.8, from whom further information can be obtained. 